\title{
Studies on magnesium in ruminant nutrition
}

\section{5.* The indirect determination of the intake of magnesium, calcium and potassium by the grazing cow}

\author{
By A. C. FIELD \\ Moredun Institute, Gilmerton, Edinburgh \\ (Received 31 December 1963-Accepted 20 February 1964)
}

A relationship exists between the mineral composition of spring pasture and the occurrence of grass tetany. Both Kemp \& 't Hart (1957) in Holland and Butler et al. $(1963)$ in Scotland found a positive correlation between the ratio, potassium content : calcium and magnesium content in herbage and the incidence of grass tetany. At present there is no information on the physiological significance of this ratio when such herbage is consumed by ruminants.

Attempts to reproduce grass tetany in adult ruminants with normal diets supplemented with K salts have been unsuccessful (Pearson, Gray \& Reiser, 1949; Eaton \& Avampato, 1952). The possibility exists that the absolute amounts of the elements as well as this ratio of $\mathrm{K}: \mathrm{Ca}$ and $\mathrm{Mg}$ in herbage is important in the aetiology of this condition. Unfortunately, there are no figures in the literature for the intakes of these elements by grazing ruminants in the spring or at other times of the year.

Estimation of the amount of a herbage constituent eaten by a grazing ruminant presents many problems, the greatest of which appears to be selective grazing. However, for $\mathrm{Mg}, \mathrm{Ca}$ and $\mathrm{K}$, it is unnecessary to sample herbage as grazed, since the ability of an adult ruminant to store these elements in its body is generally small relative to the amounts in the diet. The balance could conceivably be ignored and the intake taken to be equal to the total amount excreted in the urine, faeces and milk. Furthermore, the amounts of $\mathrm{Mg}$ and $\mathrm{Ca}$ excreted in the urine and milk are a measure of the apparent absorption, and the ratio of these amounts to the amount ingested is the apparent availability.

The difficulties associated with the total collection of excreta from a grazing cow have led to the use of an external indicator, usually chromium sesquioxide $\left(\mathrm{Cr}_{2} \mathrm{O}_{3}\right)$, to predict faecal excretion and of an internal or endogenous indicator, e.g. creatinine, to predict urinary excretion (Butcher \& Harris, 1957). The errors of prediction, which are the subject of this study, depend upon the completeness of excretion of the external indicator, day-to-day variation in the excretion of the endogenous indicator and the accuracy with which a sample can be obtained representative of all excreta passed during the collection period. The last error depends upon the diurnal variations in the excretion of the indicator and of the element to be measured.

- Paper no. 4: Brit. J. Nutr. (1962), 16, 99. 
In the study to be described here, the feasibility was examined of a technique, based on the use of markers and samples of excreta taken at mïking time, for estimating the output of $\mathrm{Ca}, \mathrm{Mg}$ and $\mathrm{K}$ in faeces and urine. It was found that the sampling error arising from diurnal variation in the ratios of the concentrations of $\mathrm{Ca}, \mathrm{Mg}$ and $\mathrm{K}$ to that of the marker was small and that the main error in the estimation of faecal outputs was in recovery of $\mathrm{Cr}_{2} \mathrm{O}_{3}$. The long-term errors in the use of a predetermined creatinine excretion in urine were not studied.

\section{EXPERIMENTAL}

Two experiments were carried out with three beef cows over to years old; $A$ and $B$ were Shorthorn $\times$ Galloway with suckling calves, $\mathrm{C}$ was a non-pregnant Shorthorn. In addition, four pairs of identical dairy twin cows were used to estimate the day-today variation in the excretion of creatinine in urine. Of the four pairs, one was Friesian and the others Friesian $\times$ Ayrshire. They were all about 5 years old and the mean weight in each pair ranged from about 400 to $625 \mathrm{~kg}$.

The experiments differed only in the nature of the diet offered. In the first experiment the cows were given hay ad lib. for 6 days before and for the 3 days of the collection period. In the second, they were transferred from pasture to stall 6 days before the 3-day collection period commenced and were given ad lib. herbage cut twice daily, morning and afternoon, from the pasture just vacated by the cows. During the collection period each defaecation and urination was caught in a receptacle by an attendant. Complete collection was achieved with faeces but not with urine, because some urine was lost before the receptacle could be placed in position. Each defaecation was weighed, mixed and sampled for chemical analysis. The volume of each urination was measured, the urine was mixed and $20 \mathrm{ml}$ were placed in a plastic bottle containing $2 \mathrm{ml} 50 \%(\mathrm{v} / \mathrm{v})$ acetic acid. A few drops of toluene were then added and the bottle and contents stored at $4^{\circ}$ until required for chemical analysis.

Capsules containing $20 \mathrm{~g}$ chromic oxide paper (Corbett, Greenhalgh, McDonald \& Florence, 1960) were made by the method described by Greenhalgh \& Runcie (1962). Each cow was given one capsule by balling gun at 8 am and 5 pm for $\mathrm{I}_{4}$ days before and during each collection period.

To investigate the variation from day to day and between animals in the excretion of creatinine, urine was collected over $24 \mathrm{~h}$ periods for a total of $\mathrm{I}_{4}$ days from the four pairs of identical twins with the equipment of van Es \& Vogt (1959).

\section{Analysis of excreta}

Faeces samples were dried to constant weight at $100-105^{\circ}$ in an electric oven with forced draught and ground in a Christy \& Norris mill with a $\mathrm{I} \mathrm{mm}$ sieve. About I $\mathrm{g}$ faeces was wet-ashed in a $500 \mathrm{ml}$ Vitreosil beaker with a mixture of $10 \mathrm{ml}$ conc. $\mathrm{NH}_{3}$ $(\mathrm{AR})$ and $5 \mathrm{ml} \mathrm{HClO}_{4}(60 \%, \mathrm{v} / \mathrm{v}, \mathrm{AR})$. When ashing was completed, water $(20 \mathrm{ml})$ was added, the sides of the beaker were scraped with a glass rod and the mixture was boiled and filtered hot into a $100 \mathrm{ml}$ volumetric flask. 
Ca was measured in suitable portions of ash solution or urine by the method of Henley \& Saunders (1958). After removal of $\mathrm{Ca}$ as oxalate, $\mathrm{Mg}$ was precipitated as $\mathrm{MgNH}_{4} \mathrm{PO}_{4}$ from the supernatant solution. The precipitate was centrifuged, washed once with $33 \%(\mathrm{v} / \mathrm{v}) \mathrm{NH}_{4} \mathrm{OH}$ and dissolved in two drops of $50 \%(\mathrm{v} / \mathrm{v}) \mathrm{HNO}_{3}$. The $\mathrm{Mg}$ was determined with ethylenediamine tetraacetic acid in the same manner as $\mathrm{Ca}$ in the method of Henley \& Saunders (1958).

$\mathrm{K}$ was determined with an EEL (Evans Electro Selenium Ltd) flame photometer after suitable dilution of the ash solution or urine. Creatinine was determined in urine by the method of Owen, Iggo, Scandrett \& Stewart (1954), and $\mathrm{Cr}_{2} \mathrm{O}_{3}$ in faeces and paper by a method similar to that of Christian \& Coup (1954).

\section{Statistical analysis}

Since the concentrations of a constituent in successive defaecations or urinations are not independent (Corbett et al. 1960), the standard deviations given in this paper have been used only as a measure of variation and not for tests of significance. To test the differences from day to day, the interaction between cows and days has been used as a measure of error.

\section{RESULTS}

\section{Urinary excretion}

The means and standard deviations of the output of creatinine ( $\mathrm{g} /$ day) by the four pairs of identical twins were $8 \cdot 8 \pm \mathrm{I} \cdot 2,9 \cdot 8 \pm \mathrm{I} \cdot 0,12 \cdot 3 \pm 0 \cdot 8,12 \cdot 7 \pm 0 \cdot 8,13 \cdot 8 \pm \mathrm{I} \cdot 5$, $14.3 \pm 1.4,15.1 \pm 2.2$ and $16.5 \pm 2.4$. The relationship between creatinine excretion and the weight of the cow was linear, the regression equation being:

creatinine excretion $(\mathrm{g} /$ day $)=0.028 \mathrm{r} \times$ weight of cow $(\mathrm{kg})-\mathrm{r} \cdot 70$.

The mean daily values for the ratios of the concentration of $\mathrm{Ca}, \mathrm{Mg}$ and $\mathrm{K}$ to that of creatinine in the two experiments with beef cows are given in Table I. Statistical analysis showed differences $(P<0.05)$ from day to day only in the ratios $\mathrm{Ca}$ :creatinine and $\mathrm{K}$ :creatinine in the second experiment.

The diurnal variations in the ratios, as measured by the coefficients of variation, are given in Table $\mathbf{r}$. In general the magnitude of the variations increased in the order, $\mathrm{K}$ :creatinine, $\mathrm{Mg}$ :creatinine and $\mathrm{Ca}$ :creatinine. The coefficients of variation remained relatively constant from day to day throughout the two experiments for $\mathrm{Mg}$ : creatinine and $\mathrm{K}$ : creatinine, but not for the other ratio. That for the ratio $\mathrm{Ca}$ :creatinine in the first experiment, for example, ranged from 16 to $77 \%$.

The diurnal variation may be due to systematic as well as random variations. To examine this possibility, differences between cows and between experiments were eliminated by expressing each value of a ratio as a fraction of its daily mean. The samples of urine were classified into periods according to the time of collection, the day being divided into $3 \mathrm{~h}$ periods. The transformed values were then pooled within ratios, within periods and within experiments and the means plotted in Fig. I.

Neither the ratio $\mathrm{K}$ : crcatinine nor $\mathrm{Mg}$ :creatinine showed well-developed diurnal rhythms, whereas with the ratio $\mathrm{Ca}$ : creatinine the diurnal rhythm depended in part on 
Table $\mathrm{r}$. Mean values and coefficient of variation $(\mathrm{cV})$ of the ratios of concentration of calcium, magnesium and potassium to that of creatinine in the urine of the cows during the two experiments

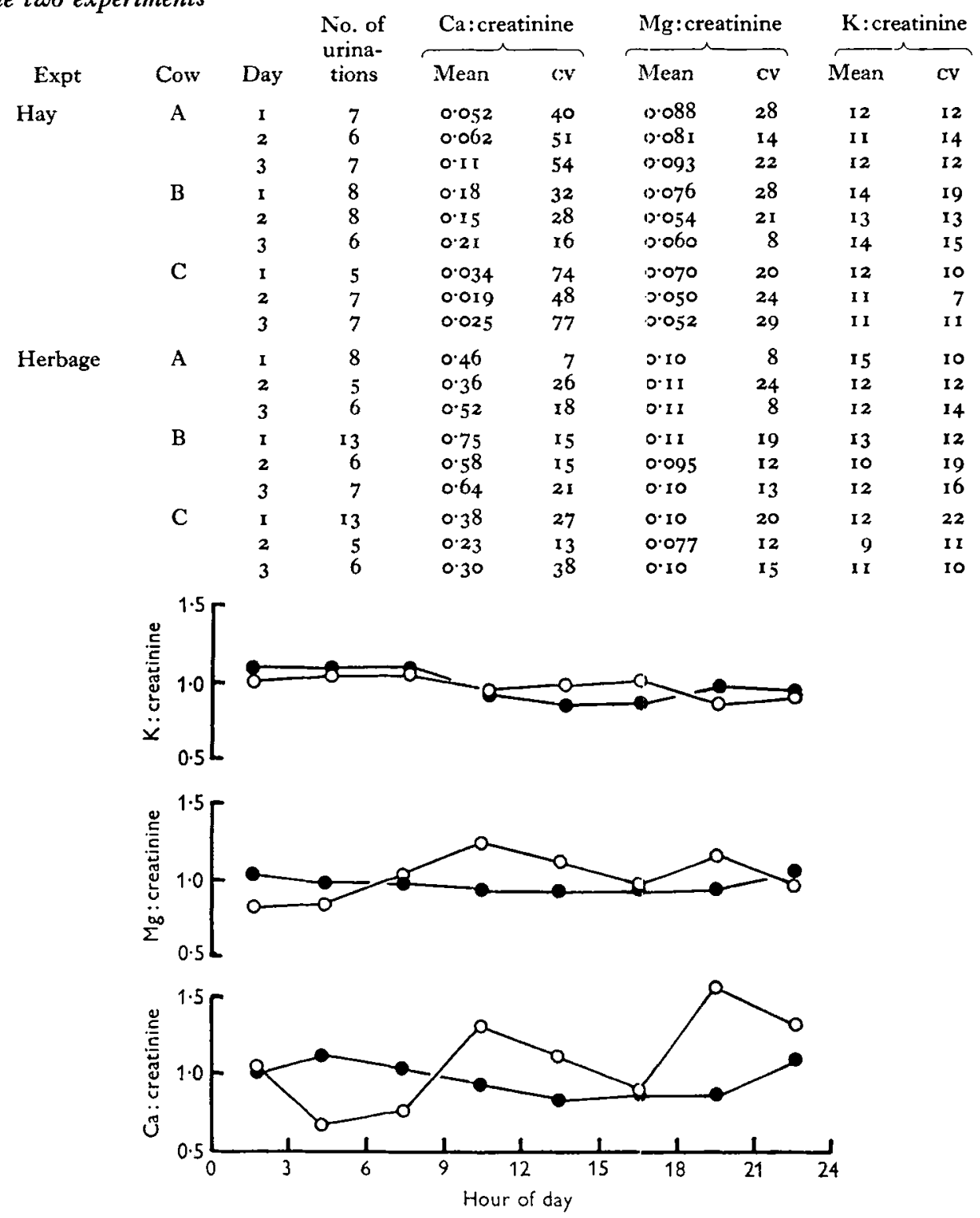

Fig. I. Diurnal variation in the ratios of the concentration of $\mathrm{Ca}$ :creatinine, $\mathrm{Mg}$ :creatinine and $\mathrm{K}$ :creatinine in cow's urine. $\circ$, hay-feeding experiment; $\bullet$, herbage-feeding experiment.

the diet of the cows. With hay, the values found from 9 am to midnight were high but with herbage they were low.

In experiments with dairy cows the most convenient time to take samples of urine and faeces is at milking. Since the amplitudes of the diurnal rhythm of the ratios 
$\mathrm{Mg}$ : creatinine and $\mathrm{K}$ : creatinine were not large, the error introduced by this sampling procedure was examined. The values of the ratios obtained for the first sample of urine collected after $8 \mathrm{am}$ and $5 \mathrm{pm}$ were pooled within ratios and within experiments. The means multiplied by the 3 -day output of creatinine gave an estimate of the amount of a urinary constituent excreted over the 3 -day period. The differences between the actual excretion and the estimates, expressed both in absolute terms and as a percentage of the actual excretion, are given in Table 2. The sampling procedure introduced a bias in the estimation of $\mathrm{Ca}$, but not of $\mathrm{Mg}$ and $\mathrm{K}$, output in urine. The percentage errors in output ranged from $+1 \cdot 6$ to +18 for $\mathrm{Ca},-16$ to $+7 \cdot 0$ for $\mathrm{Mg}$ and -3.4 to $+5.7 \%$ for $\mathrm{K}$.

Table 2. The differences between actual and estimated excretion of calcium, magnesium and potassium during each collection period in the two experiments, expressed in $g$ and as a percentage of actual excretion

(The estimated excretion was obtained by multiplying the 3-day excretion of creatinine by the mean value of the ratios found in the samples of urine taken at milking time)

\begin{tabular}{|c|c|}
\hline $\begin{array}{c}\text { Urinary } \\
\text { con- } \\
\text { stituent }\end{array}$ & Expt \\
\hline $\mathrm{Ca}$ & $\begin{array}{l}\text { Hay } \\
\text { Herbage }\end{array}$ \\
\hline $\mathbf{M g}$ & $\begin{array}{l}\text { Hay } \\
\text { Herbage }\end{array}$ \\
\hline $\mathbf{K}$ & $\begin{array}{l}\text { Hay } \\
\text { Herbage }\end{array}$ \\
\hline
\end{tabular}

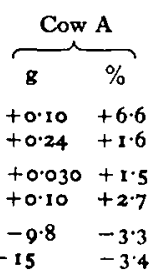
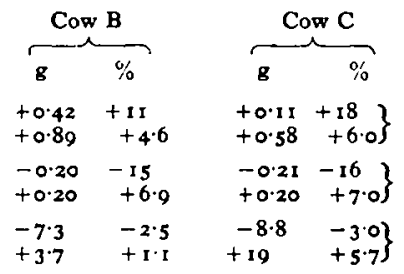

$$
\begin{array}{ll}
\text { Mean }(g) \pm S D & M e a n(\%) \\
+0.390 \pm 0.306 & +8.06 \\
+0.0212 \pm 0.188 & -2.13 \\
-2.95 \pm 12.6 & -0.89
\end{array}
$$

\section{Faecal excretion}

The mean daily values for the ratios of concentration of $\mathrm{Ca}, \mathrm{Mg}$ and $\mathrm{K}$ to that of $\mathrm{Cr}_{2} \mathrm{O}_{3}$ found in the two experiments with beef cows are given in Table 3. Differences from day to day occurred in the ratios $\mathrm{Ca}: \mathrm{Cr}_{2} \mathrm{O}_{3}$ and $\mathrm{Mg}: \mathrm{Cr}_{2} \mathrm{O}_{3}$ in the hay-feeding experiment $(P<0.01)$ and in the ratio $\mathrm{Mg}: \mathrm{Cr}_{2} \mathrm{O}_{3}$ in the experiment with herbage $(P<0.05)$.

The diurnal variations in the ratios, as measured by the coefficient of variation, are given in Table 3. The coefficients of variation for the three ratios were similar to one another and remained relatively constant from day to day throughout the two experiments.

To examine the diurnal variation for systematic variations, the values for the ratios in the sample of faeces were treated in the same way as those for urine. The means of the eleven to twenty values obtained for each ratio in each $3 \mathrm{~h}$ interval are plotted in Fig. 2. None of the ratios showed a well-defined diurnal rhythm, but there was a tendency for the values for the ratios $\mathrm{Ca}: \mathrm{Cr}_{2} \mathrm{O}_{3}$ and $\mathrm{Mg}: \mathrm{Cr}_{2} \mathrm{O}_{3}$ to be lower in the evening and higher in the hours of daylight.

When marker and grab-sample techniques are employed there are two error components in the estimate of the quantity of faecal or urinary constituent excreted in a given period. These are a long-term component resulting from the failure of marker output to equal input and a short-term component associated with the sampling error (Langlands, Corbett, McDonald \& Reid, 1963). To examine the short-term error 
Table 3. Mean values and coefficients of variation $(\mathrm{CV})$ of the ratios of the concentration of calcium, magnesium and potassium to that of $\mathrm{Cr}_{2} \mathrm{O}_{3}$ in the faeces of the cows during the two experiments

\begin{tabular}{|c|c|c|c|c|c|c|c|c|c|}
\hline \multirow[b]{2}{*}{ Expt } & \multirow[b]{2}{*}{ Cow } & \multirow[b]{2}{*}{ Day } & \multirow{2}{*}{$\begin{array}{l}\text { No. of } \\
\text { defaeca- } \\
\text { tions }\end{array}$} & \multicolumn{2}{|c|}{$\mathrm{Ca}: \mathrm{Cr}_{2} \mathrm{O}_{3}$} & \multicolumn{2}{|c|}{$\mathrm{Mg}: \mathrm{Cr}_{2} \mathrm{O}_{3}$} & \multicolumn{2}{|c|}{$\mathrm{K}: \mathrm{Cr}_{2} \mathrm{O}_{3}$} \\
\hline & & & & Mean & $\mathrm{CV}$ & Mean & $\mathrm{CV}$ & Mean & $\mathrm{cv}$ \\
\hline \multirow[t]{9}{*}{ Hay } & A & I & 13 & $3 \cdot 3$ & 18 & 0.97 & 20 & $4 \cdot 8$ & I8 \\
\hline & & 2 & 12 & $2 \cdot 9$ & I 5 & 0.79 & 2 I & $5^{\cdot 6}$ & 16 \\
\hline & & 3 & I0 & $2 \cdot 6$ & II & 0.65 & 14 & $5 \cdot 3$ & 26 \\
\hline & B & $\mathbf{I}$ & 19 & $2 \cdot 8$ & 12 & 0.96 & 23 & $3 \cdot 5$ & 22 \\
\hline & & 2 & 16 & $2 \cdot 4$ & 10 & 0.67 & 15 & $3 \cdot 3$ & 9 \\
\hline & & 3 & 16 & $2 \cdot 2$ & 10 & 0.69 & 17 & $3 \cdot 1$ & 18 \\
\hline & C & I & 12 & $2 \cdot 8$ & II & 0.86 & 14 & $2 \cdot 2$ & I3 \\
\hline & & 2 & 12 & $2 \cdot 5$ & IO & 0.71 & I3 & $2 \cdot 5$ & 9 \\
\hline & & 3 & 12 & $2 \cdot 3$ & I I & 0.59 & 12 & $2 \cdot 6$ & I7 \\
\hline \multirow[t]{9}{*}{ Herbage } & $\mathbf{A}$ & I & 15 & 4.4 & 17 & $\mathrm{I} \cdot \mathbf{2}$ & 24 & 3.7 & 28 \\
\hline & & 2 & 12 & $3 \cdot 8$ & 9 & $I \cdot I$ & 9 & $4 \cdot 2$ & 10 \\
\hline & & 3 & 13 & $3 \cdot 2$ & 10 & 0.99 & 9 & $5 \cdot 4$ & I3 \\
\hline & B & I & 16 & $2 \cdot 7$ & 14 & $0.8 \mathrm{I}$ & 19 & I.7 & 8 \\
\hline & & 2 & $x 6$ & $2 \cdot 6$ & II & 0.83 & 10 & $2 \cdot 2$ & 28 \\
\hline & & 3 & I 4 & $2 \cdot 2$ & I I & 0.69 & 8 & $I \cdot 9$ & 10 \\
\hline & C & $\mathbf{I}$ & 15 & $3 \cdot 0$ & I3 & 0.77 & 15 & $2 \cdot 0$ & I4 \\
\hline & & 2 & 12 & 3.0 & 8 & 0.74 & IO & $I \cdot 9$ & I4 \\
\hline & & 3 & 9 & $2 \cdot 6$ & 8 & 0.66 & 9 & $I \cdot 7$ & I I \\
\hline
\end{tabular}
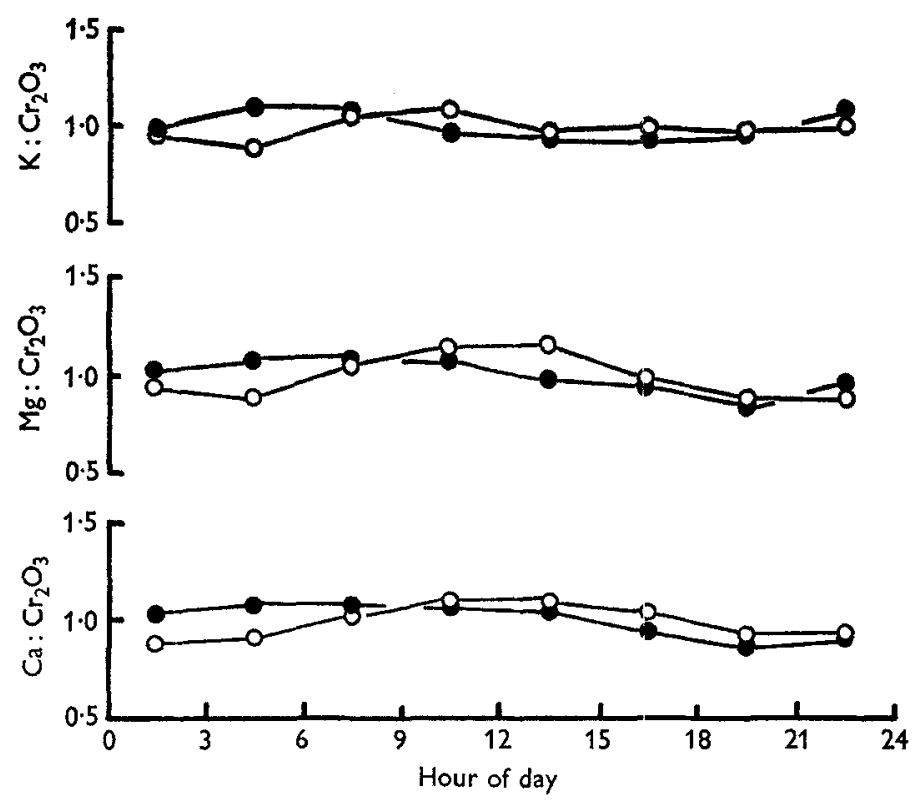

Fig. 2. Diurnal variation in the ratios of the concentration of $\mathrm{Ca}: \mathrm{Cr}_{2} \mathrm{O}_{3}, \mathrm{Mg}: \mathrm{Cr}_{2} \mathrm{O}_{3}$ and $\mathrm{K}: \mathrm{Cr}_{2} \mathrm{O}_{3}$ in cow's faeces. $\mathrm{O}$, hay-feeding experiment; $\bullet$, herbage-feeding experiment. 
introduced by sampling at milking times, the values of the ratios obtained for the first sample of faeces collected after $8 \mathrm{am}$ and $5 \mathrm{pm}$ were pooled within ratios and within experiments. The short-term errors, which are equal to the difference between the ratios $\mathrm{Ca}, \mathrm{Mg}$ or $\mathrm{K}: \mathrm{Cr}_{2} \mathrm{O}_{3}$ in grab-samples and samples based on total collection multiplied by the quantity of $\mathrm{Cr}_{2} \mathrm{O}_{3}$ administered in the collection period, are given in Table 4; they are expressed both in absolute terms and as a percentage of the actual excretion. The sampling procedure introduced a bias into the estimates of the output of $\mathrm{Ca}$ but not into those for the output of the other constituents; there was a tendency to underestimate $\mathrm{Ca}$ output by $0.48-5 \cdot 3 \%$. The short-term errors were smaller for $\mathrm{Mg}$ than for $\mathrm{K}$; they ranged from $-4 \cdot 4$ to $+4 \cdot 7$ for $\mathrm{Mg}$ and from -17 to $+9 \cdot 7 \%$ for $\mathrm{K}$.

Table 4. The short-term error due to sampling at milking times in the estimate of the faecal output of calcium, magnesium and potassium in each collection period in the two experiments, expressed in $g$ and as a percentage of actual output

(The error was obtained by multiplying the quantity of $\mathrm{Cr}_{2} \mathrm{O}_{3}$ administered in the collection period by the difference between the ratios in grab and representative samples of faeces)

\begin{tabular}{|c|c|c|c|c|c|c|c|c|c|}
\hline \multirow{2}{*}{$\begin{array}{l}\text { Faecal } \\
\text { con- } \\
\text { stituent }\end{array}$} & \multirow[b]{2}{*}{ Expt } & \multicolumn{2}{|c|}{ Cow A } & \multicolumn{2}{|c|}{ Cow B } & \multicolumn{2}{|c|}{ Cow C } & \multirow[b]{2}{*}{ Mean (\%) } & \multirow{2}{*}{$\begin{array}{c}\text { Overall mean } \\
(\%)\end{array}$} \\
\hline & & $\mathbf{g}$ & $\%$ & $\mathbf{8}$ & $\%$ & R & $\%$ & & \\
\hline $\mathrm{Ca}$ & $\begin{array}{l}\text { Hay } \\
\text { Herbage }\end{array}$ & $\begin{array}{l}-1 \cdot 1 \\
-2 \cdot 9\end{array}$ & $\begin{array}{l}-1 \cdot 2 \\
-2 \cdot 6\end{array}$ & $\begin{array}{l}-3 \cdot 2 \\
-0.36\end{array}$ & $\begin{array}{l}-3.9 \\
-0.48\end{array}$ & $\begin{array}{l}-3 \cdot 9 \\
-5.0\end{array}$ & $\begin{array}{l}-5 \cdot 0 \\
-5 \cdot 3\end{array}$ & $\left.\begin{array}{l}-3.4 \\
-2.8\end{array}\right\}$ & $-3 \cdot 1$ \\
\hline $\mathbf{M g}$ & $\begin{array}{l}\text { Hay } \\
\text { Herbage }\end{array}$ & $\begin{array}{l}+1.1 \\
-1.4\end{array}$ & $\begin{array}{l}+47 \\
-4 \cdot 4\end{array}$ & $\begin{array}{l}+0.75 \\
-0.93\end{array}$ & $\begin{array}{l}+2 \cdot 9 \\
-4 \cdot 1\end{array}$ & $\begin{array}{l}+0.25 \\
-0.61\end{array}$ & $\begin{array}{l}+1 \cdot 1 \\
-2 \cdot 6\end{array}$ & $\left.\begin{array}{l}+2 \cdot 9 \\
-3 \cdot 7\end{array}\right\}$ & -0.40 \\
\hline $\mathrm{K}$ & $\begin{array}{l}\text { Hay } \\
\text { Herbage }\end{array}$ & $\begin{array}{l}+6.4 \\
+12\end{array}$ & $\begin{array}{l}+4 \cdot 2 \\
+9 \cdot 7\end{array}$ & $\begin{array}{l}+5.7 \\
-1.8\end{array}$ & $\begin{array}{l}+5 \cdot 2 \\
-3 \cdot 1\end{array}$ & $\begin{array}{l}-12 \\
-1.4\end{array}$ & $\begin{array}{l}-17 \\
+2.3\end{array}$ & $\left.\begin{array}{l}-2.5 \\
+3.0\end{array}\right\}$ & +0.25 \\
\hline
\end{tabular}

The long-term error is equal to the concentration of $\mathrm{Ca}, \mathrm{Mg}$ or $\mathrm{K}$ in the representative sample of faeces multiplied by the difference between the actual and estimated faecal output; the latter is equal to the ratio of the amount of $\mathrm{Cr}_{2} \mathrm{O}_{3}$ administered to the concentration of $\mathrm{Cr}_{2} \mathrm{O}_{3}$ in the representative sample of faeces. When the error is expressed as a percentage of the actual output of $\mathrm{Ca}, \mathrm{Mg}$ or $\mathrm{K}$, it is the same for all faecal constituents measured. These values were, respectively, for the cows A, B and $\mathrm{C}:-17,-6$ and $-15 \%$ in the hay-feeding experiment and $-22,-20$ and $-8 \%$ in the herbage-feeding experiment. The fact that all values were negative indicated that the recovery of $\mathrm{Cr}_{2} \mathrm{O}_{3}$ was incomplete. The mean loss for all animals was $\mathrm{I}_{3}$ and ${ }_{17} \%$ in the hay- and herbage-feeding experiments respectively. An estimate of the random component of the long-term error can be made from the standard deviation of the errors for the cows in the two experiments. The standard deviations, expressed as a percentage of mean actual output, were $\pm 9.50, \pm 8.25$, and $\pm 10.4 \%$ for $\mathrm{Ca}, \mathrm{Mg}$ and $\mathrm{K}$ respectively.

The total errors, i.e. difference between actual and estimated faecal outputs of $\mathrm{Ca}, \mathrm{Mg}$ or $\mathrm{K}$, expressed in $\mathrm{g}$ and as a percentage of actual excretion, are given in Table 5 . The estimated output was calculated by multiplying the concentration of $\mathrm{Ca}$, $\mathrm{Mg}$ or $\mathrm{K}$ in the grab-sample by the estimated dry-matter faecal output. All estimates underestimated the excretion of $\mathrm{Ca}, \mathrm{Mg}$ and $\mathrm{K}$ by from $\mathrm{I}$ to $3 \mathrm{I} \%$. The total error in the estimate of the quantity of faeces excreted by each cow in each experiment was 
Table 5. The difference between the actual and estimated faecal output of calcium, magnesium and potassium, expressed in $g$ and as a percentage of actual output in each collection period in the two experiments

(The estimated output was obtained by multiplying the concentration of the faecal constituents in the grab-samples taken at milking time by the estimated faecal output of dry matter)

\begin{tabular}{|c|c|c|c|c|c|c|c|c|}
\hline \multirow{2}{*}{$\begin{array}{c}\text { Faecal } \\
\text { constituent }\end{array}$} & \multirow[b]{2}{*}{ Expt } & \multicolumn{2}{|c|}{ Cow $A$} & \multicolumn{2}{|c|}{ Cow B } & \multicolumn{2}{|c|}{ Cow C } & \multirow[b]{2}{*}{ Overall mean $(0)$} \\
\hline & & $\mathrm{g}$ & $\%$ & $\mathbf{g}$ & $\%$ & g & $\%$ & \\
\hline $\mathrm{Ca}$ & $\begin{array}{l}\text { Hay } \\
\text { Herbage }\end{array}$ & $\begin{array}{l}-16 \\
-28\end{array}$ & $\begin{array}{l}-19 \\
-25\end{array}$ & $\begin{array}{l}-8 \cdot 3 \\
-16\end{array}$ & $\begin{array}{l}-10 \\
-21\end{array}$ & $\begin{array}{l}-15 \\
-12\end{array}$ & $\left.\begin{array}{l}-20 \\
-13\end{array}\right\}$ & $-18 \cdot 0$ \\
\hline $\mathrm{Ng}$ & $\begin{array}{l}\text { Hay } \\
\text { Herbage }\end{array}$ & $\begin{array}{l}-3.0 \\
-8.7\end{array}$ & $\begin{array}{l}-13 \\
-27\end{array}$ & $\begin{array}{l}-0.87 \\
-5.6\end{array}$ & $\begin{array}{l}-3 \cdot 3 \\
-25\end{array}$ & $\begin{array}{l}-3 \cdot 0 \\
-2 \cdot 5\end{array}$ & $\left.\begin{array}{l}-14 \\
-10\end{array}\right\}$ & -15.4 \\
\hline K & $\begin{array}{l}\text { Hay } \\
\text { Herbage }\end{array}$ & $\begin{array}{l}-20 \\
-16\end{array}$ & $\begin{array}{l}-13 \\
-13\end{array}$ & $\begin{array}{l}-I \cdot I \\
-13\end{array}$ & $\begin{array}{l}-1 \cdot 0 \\
-24\end{array}$ & $\begin{array}{l}-23 \\
-6 \cdot 3\end{array}$ & $\left.\begin{array}{l}-31 \\
-10\end{array}\right\}$ & -15.3 \\
\hline
\end{tabular}

calculated. The mean and standard deviations of the errors, expressed as a percentage of the mean actual faecal output, were $-14 \cdot 6$ and $\pm 8 \cdot 21 \%$ respectively.

\section{DISCUSSION}

The proposed indirect method for estimating the arnount of $\mathrm{Mg}, \mathrm{Ca}$ or $\mathrm{K}$ eaten by a grazing ruminant has inherent errors, the number and relative importance of which depend upon the chemical element in question, the species and physiological state of the experimental animal. Pregnancy, for example, introduces errors through storage in the developing foetus.

One possible source of error is the balance of $\mathrm{Mg}, \mathrm{Ca}$ or $\mathrm{K}$ which unfortunately is difficult to assess quantitatively. The balance is not a direct observation and is subject to the cumulative errors attached to all measurements in a balance trial, and mineral balances are in general small relative to both intake and excretion. An assessment of the error involved, however, may be made from our knowledge of the physiology of individual elements, from the mineral content in the body of foetuses of different ages and from cumulative balances over relatively long periods.

Changes in the content of $\mathrm{Ca}$ and $\mathrm{Mg}$ in the body of dairy cows are cyclical. $\mathrm{Ca}$ and $\mathrm{Mg}$ are lost from the body in early lactation, changing to retention late in lactation, in the dry period and especially during the last 3 months o: gestation (Forbes, 1935). An estimate of the $\mathrm{Ca}$ loss during early lactation can be made from the cumulative losses between calving and the attainment of positive balance by cows (Duncan, 1958). The daily losses range from $5^{.6}$ to $10.0 \mathrm{~g}$ with a mean of $7.5 \mathrm{~g}$, which represents $5-15 \%$ of the normal $\mathrm{Ca}$ intake of dairy cows. The concomitant loss of $\mathrm{Mg}$ in the breakdown of bone mineral to provide $\mathrm{Ca}$ for lactation during the first 3 months of lactation is $0.2 \mathrm{~g} /$ day, calculated from the $\mathrm{Ca}$ loss from bone and the ratio of $\mathrm{Ca}: \mathrm{Mg}(45: \mathrm{I})$ in bone (Blaxter \& Rook, 1954). From the data collected by Duncan (1958) for the Ca content of foetuses of difference ages, it can be estimated that during the last 3 months of gestation the Ca content of the Hereford calves analysed by Hogan \& Nierman (1927) increased by $2 \mathrm{~g} /$ day, whereas that of the dairy calves of Ellenberger, Newlander $\&$ Jones ( $195^{\circ}$ ) increased by $9 \mathrm{~g} /$ day. A correction for this retention, which can lead to the $\mathrm{Ca}$ intake being underestimated with the proposed method by about $20 \%$ in 
extreme conditions, can be obtained easily from the weight of the newborn calf and the Ca content of newborn calves. The corresponding value for the daily increments of $\mathrm{Mg}$ in the developing foetus is $0.3 \mathrm{~g}$. This value was estimated as follows: the storage of $\mathrm{Mg}$ in the foetal skeleton, from the Ca retention ( $9 \mathrm{~g} /$ day) and the ratio of $\mathrm{Ca}: \mathrm{Mg}$ $(40: \mathrm{I})$ in foetal bone (Forbes, 1935), and in soft tissue from the increase in soft tissue (400 $\mathrm{g} /$ day; Hammond, 1927) and the concentration of $\mathrm{Mg}$ in foetal soft tissue (0.02\%; Forbes, 1935).

For the regulation of osmotic pressure and acid-base balance, the concentration of $\mathrm{K}$ in the body fluids and cells must be kept within narrow limits. The body, therefore, has a very efficient system of preventing changes in the content of $\mathrm{K}$ in the body by excreting the $\mathrm{K}$ which is always absorbed in excess of requirements. The daily retention of $\mathrm{K}(0.75 \mathrm{~g})$ in the body of the developing foetus over the last 3 months of gestation is negligibly small relative to intake. The retention was calculated from the increase in weight of a calf foetus (Hammond, 1927) and the values for the concentration of $\mathrm{K}$ in whole calf foetus given by Blaxter \& Rook (1956a). Blaxter \& Rook $(1956 b$ ) found that sheep lost up to $\mathrm{g} \mathrm{K} /$ day through the skin, which is only $2-4 \%$ of intake (Field, unpublished observation).

It is noteworthy that the experimental design must avoid rapid changes in the composition of the diet, since these changes will lead to large errors in the estimated intake because of changes in gut fill, a site of mineral storage, and because of the carry-over effect of faeces from the precollection period. For example, it is generally recognized that the onset of grazing in the spring causes a large change in gut fill.

In the experiment described in this paper the proposed indirect method underestimated the faecal excretion of $\mathrm{Ca}, \mathrm{Mg}$ and $\mathrm{K}$ by about $\mathrm{r} 3-\mathrm{I} 8 \%$. This bias was due mainly to $\mathrm{Cr}_{2} \mathrm{O}_{3}$ output being less than $\mathrm{Cr}_{2} \mathrm{O}_{3}$ intake over the period of estimation. The mean losses of $\mathrm{Cr}_{2} \mathrm{O}_{3}$ for all the animals were 12.7 and $17.0 \%$ in the hay- and herbage-feeding experiments respectively. These observations are similar to, but the figures are greater than, those reported by Langlands et al. (1963) for grazing steers given $\mathrm{Cr}_{2} \mathrm{O}_{3}$ paper. They found a mean loss of $6 \cdot \mathrm{I} \%$ during the collection period of 18 days and attributed it to the incomplete collection of facces, a cause which would not operate under our experimental conditions. There are many reports in the literature of incomplete recovery of $\mathrm{Cr}_{2} \mathrm{O}_{3}$. Stevenson (1962), reviewing the literature, quotes recoveries ranging from $85.4 \%$ for a 3 -day collection period to $100.7 \%$ for collection periods of much longer duration. It is, therefore, probable that the low recovery of $\mathrm{Cr}_{2} \mathrm{O}_{3}$ in our experiments arose partly from the shortness of the collection period and partly from the use of a Christy \& Norris mill to grind the dried faeces samples. Samples produced by such a mill contained $2 \cdot 7 \%$ less $\mathrm{Cr}_{2} \mathrm{O}_{3}$ than similar faeces ground with a Wiley mill (Stevenson, 1962). The low recovery may have been due to a reluctance of the animal to defaecate under the system of collection. This effect must have operated throughout the collection period since the day-to-day variation in recovery of $\mathrm{Cr}_{2} \mathrm{O}_{3}$ showed no consistent trend within each 3 -day period. Unfortunately it was not possible to measure feed intake, which would have thrown some light on the low recovery. The taking of grab-samples at milking time was satisfactory for $\mathrm{K}$ and $\mathrm{Mg}$ in so far as no systematic errors were introduced in the estimates of faecal output. 
On the other hand, with $\mathrm{Ca}$ there was a small underestimation ranging from $\mathrm{I}$ to $5 \%$. With an error of this magnitude, it is preferable to ignore it rather than lose the convenience of the sampling technique. It must be pointed out that the above discussion on the errors inherent in the use of $\mathrm{Cr}_{2} \mathrm{O}_{3}$ and grab-sarapling techniques apply only to studies with cattle, since total collection is practised with sheep and only the normal sampling and analytical errors apply.

The use of creatinine as indicator for the output of urine presents a number of problems. The error arising from the difference between the actual and predicted creatinine output over the period of estimation has two components. The long-term error which causes a bias arises from changes in the fat-firee mass of the body and not from changes in age, state of fatness, the amount and nature of the diet (Van Niekerk, Reid, Bensadoun \& Paladines, 1963) or in pregnancy and lactation (Field, unpublished observations). Although not determined in this experiment, the long-term error will be small for mature animals. The short-term errors which give rise to the random variation arise from the day-to-day variation in creatinine output. The coefficient of variation for the eight cows ranged from 6.3 to $14.7 \%$ with a mean of $10.8 \%$. These values are in good agreement with the mean value of $6.3 \%$ fourd for the inter-day coefficient of variation in urinary creatinine excretion of sheep (Van Niekerk, Bensadoun, Paladines $\&$ Reid, i 963 ). Thus the short-term errors wo dld give rise to a coefficient of variation of $4-7 \%$ in the output of urine over a 3 -day collection period.

The sampling technique was satisfactory for both $\mathrm{K}$ and $\mathrm{Mg}$ but led to a small underestimation of urinary excretion $(0.13 \mathrm{~g} /$ day) of $\mathrm{Ca}$. Since only a small proportion $(<5 \%$ ) of the $\mathrm{Ca}$ is excreted through the kidney, it is better to disregard the error for the convenience of the sampling technique. It was not possible to determine the total error in the estimates of urinary output directly and, since it is not known whether the long- and short-term errors are independent, it was not possible to derive an accurate figure for the total error. Since the error in the estimated urinary output, arising out of the sampling technique, ranged from 0.1 to $1.0 \%$ of the intakes of $\mathrm{Ca}$ and $\mathrm{Mg}$ and from $\mathrm{I}$ to $5 \%$ of the intake of $\mathrm{K}$, and since the errors associated with creatinine output $(4-7 \%)$ are small, the error in dietary intake arising from the error in urinary output will be small.

To summarize, the error introduced into estimates of intake by ignoring the balance is only of importance for $\mathrm{Ca}$, the dietary intake being overestimated in early lactation and underestimated in the last 3 months of gestation. The major source of error in the estimate of the dietary intake of $\mathrm{Ca}$ and $\mathrm{Mg}$ is in the recovery of $\mathrm{Cr}_{2} \mathrm{O}_{3}$, and this may be reduced by increasing the length of the collection period and by less artificial experimental conditions. Samples of urine and faeces taken at milking time appear to be suitable for $\mathrm{Mg}$ and $\mathrm{K}$; a small but systematic underestimation is introduced for $\mathrm{Ca}$ which is approximately $\mathrm{I}-5 \%$ of intake. It is possible, however, that the system of sampling is not satisfactory for the grazing animal. Finally, the quantitative relationship between the error of a method and the difference to be measured should not be forgotten. The variations in the daily intake of grazing cows, some given concentrates, throughout the grazing season were from 60 to $170 \mathrm{~g}$ for $\mathrm{Ca}$, from 17 to $34 \mathrm{~g}$ for $\mathrm{Mg}$ and from 200 to $400 \mathrm{~g}$ for K (Field, unpublished resulrs). 


\section{SUMMARY}

I. All defaecations and urinations were collected by attendants for 3 days from three old cows given first hay and secondly cut herbage. Each cow was dosed twice daily with a standard quantity of chromium sesquioxide $\left(\mathrm{Cr}_{2} \mathrm{O}_{3}\right)$ incorporated in a specially prepared paper. The concentration and amounts of $\mathrm{Ca}, \mathrm{Mg}$ and $\mathrm{K}$ were determined in the samples of excreta, that of $\mathrm{Cr}_{2} \mathrm{O}_{3}$ in the samples of facces and that of creatinine in the samples of urine.

2. To determine the day-to-day variation in the excretion of creatinine, urine was collected over $24 \mathrm{~h}$ periods for a total of 14 days from each of eight cows. The coefficient of variation of the daily output of creatinine for each of the cows ranged from 6.3 to $14.7 \%$ with a mean of $10.8 \%$.

3. In general, the diurnal variation in the ratios of the concentration of $\mathrm{Ca}, \mathrm{Mg}$ and $\mathrm{K}$ to that of creatinine were, in order of increasing coefficient of variation, $\mathrm{K}$ : creatinine, $\mathrm{Mg}$ :creatinine and $\mathrm{Ca}$ :creatinine. None of the ratios showed well-developed diurnal rhythms.

4. The error in the urinary output arising from sampling only at milking time ranged from 0.1 to $1.0 \%$ of the intake of $\mathrm{Ca}$ and of $\mathrm{Mg}$ and from $\mathrm{I}$ to $5 \%$ of the intake of $\mathrm{K}$.

5. None of the ratios of concentrations of $\mathrm{Ca}, \mathrm{Mg}$ and $\mathrm{K}$ to that of $\mathrm{Cr}_{2} \mathrm{O}_{3}$ in faeces showed well-defined diurnal cycles, but there was a tendency for the ratio $\mathrm{Ca}: \mathrm{Cr}_{2} \mathrm{O}_{3}$ to be lower in the evenings and higher in daylight.

6. Measured faecal outputs were compared with the output estimated from the concentrations of $\mathrm{Ca}, \mathrm{Mg}, \mathrm{K}$ and $\mathrm{Cr}_{2} \mathrm{O}_{3}$ in grab-samples of faeces voided at milking time. All estimates underestimated the measured excretion by about $13-18 \%$, mainly because of $\mathrm{Cr}_{2} \mathrm{O}_{3}$ output being less than $\mathrm{Cr}_{2} \mathrm{O}_{3}$ intake over the period of estimation and not because of the sampling procedure.

7. The errors associated with the proposed method have been discussed. It was concluded that the error due to taking samples of urine and faeces at milking time was small, the major source of error in the determination of $\mathrm{Ca}$ and $\mathrm{Mg}$ in excreta was the low recovery of $\mathrm{Cr}_{2} \mathrm{O}_{3}$ and the error introduced by ignoring the balance was of importance only for $\mathrm{Ca}$.

I thank Mrs N. M. Fisher and Messrs A. J. Minto, A. G. Brown and D. M. Pollock for skilled technical assistance.

\section{REFERENCES}

Blaxter, K. L. \& Rook, J. A. F. (1954). Э. comp. Path. 64, 157.

Blaxter, K. L. \& Rook, J. A. F. (1956a). F. agric. Sci. 48, 194.

Blaxter, K. L. \& Rook, J. A. F. (1956b). Э. agric. Sci. 48, 210.

Butcher, J. E. \& Harris, L. E. (1957). 7. Anim. Sci. 16, 1020.

Butler, E. J. \& Veterinary Investigation and Agricultural Advisory Officers of the East and West of Scotland Agricultural Colleges (1963). F. agric. Sci. 6o, 329.

Christian, K. R. \& Coup, M. R. (1954). N.Z. F. Sci. Tech. A, 36, 328.

Corbett, J. L., Greenhalgh, J. F. D., McDonald, I. \& Florence, E. (1960). Brit. F. Nutr. 14, 289.

Duncan, D. L. (1958). Nutr. Abstr. Rev. 28, 695 .

Eaton, H. D. \& Avampato, J. E. (1952). J. Anim. Sci. 11, 761.

Ellenberger, H. B., Newlander, J. A. \& Jones, C. H. (1950). Bull. Vt agric. Exp. Sta. no. $55^{8}$. 
Forbes, E. B. (1935). Bull. Pa agric. Exp. Sta. no. 319.

Greenhalgh, J. F. D. \& Runcie, K. V. (1962). Y. agric. Sci. 59, 95.

Hammond, J. (1927). The Physiology of Reproduction in the Cozv. Cambridge University Press.

Henley, A. A. \& Saunders, R. A. (1958). Analyst, 83, 584 .

Hogan, A. G. \& Nierman, J. L. (1927). Res. Bull. Mo. agric. Exp. Sta. no. 107.

Kemp, A. \& 't Hart, M. L. (1957). Neth. J. agric. Sci. 5, 4.

Langlands, J. P., Corbett, J. L., McDonald, I. \& Reid, G. W. (1963). Brit. Y. Nutr. r7, 2 I I.

Owen, J. A., Iggo, B., Scandrett, F. J. \& Stewart, C. P. (1954). Biochem. Y. 58, 426.

Pearson, P. B., Gray, J. A. \& Reiser, R. (1949). J. Anim. Sci. 8, 52.

Stevenson, A. E. (1962). N.Z. F. agric. Res. 5, 339.

Van Es, A. J. H. \& Vogt, J. E. (1959). F. Anim. Sci. 18, 1 220.

Van Niekerk, B. D. H., Bensadoun, A., Paladines, O. L. \& Reid, J. T. (1963). Y. Nutr. 79, 373.

Van Niekerk, B. D. H., Reid, J. T., Bensadoun, A. \& Paladines, C. L. (r963). Y. Nutr. 79, 463. 